University of Nebraska - Lincoln

DigitalCommons@University of Nebraska - Lincoln

1980

\title{
Faulting Patterns in North-Central Nevada and Strength of the Crust
}

Mary Lou Zoback

U.S. Geological Survey, marylouz@stanford.edu

Mark D. Zoback

U.S. Geological Survey, zoback@stanford.edu

Follow this and additional works at: https://digitalcommons.unl.edu/usgsstaffpub

Part of the Earth Sciences Commons

Zoback, Mary Lou and Zoback, Mark D., "Faulting Patterns in North-Central Nevada and Strength of the Crust" (1980). USGS Staff -- Published Research. 452.

https://digitalcommons.unl.edu/usgsstaffpub/452

This Article is brought to you for free and open access by the US Geological Survey at DigitalCommons@University of Nebraska - Lincoln. It has been accepted for inclusion in USGS Staff -- Published Research by an authorized administrator of DigitalCommons@University of Nebraska - Lincoln. 


\title{
Faulting Patterns in North-Central Nevada and Strength of the Crust
}

\author{
MARY LOU ZOBACK AND MARK D. ZOBACK
}

\author{
U.S. Geological Survey, Menlo Park, California 94025
}

\begin{abstract}
NNE normal fault trends characterize much of the northern Basin and Range province. These faults make sharp bends to NNW and ENE trends in north-central Nevada in the vicinity of a mid-Miocene rift characterized by a zone of diabase dike swarms, graben-filling flows, and a coinciding aeromagnetic anomaly. Despite a roughly $45^{\circ}$ change in the least principal stress direction since mid-Miocene time, pre-existing NNW- and ENE-trending faults in the vicinity of the rift accommodated the extension whereas regionally, major crustal blocks were faulted along a NNE trend, approximately perpendicular to the modern least principal stress direction. An assumed uniform regional stress field (derived from geologic and geophysical indicators of the modern principal stress field) and the observed oblique slip on the pre-existing faults were combined in an analysis utilizing an empirically derived frictional sliding law and the Coulomb failure criterion. This analysis constrained the ratio of the least principal stress to the greatest principal stress $\left(S_{3} / S_{1}\right)$ as well as the inherent shear strength of intact crustal rocks, $\tau_{c}$. While both parameters, $S_{3} / S_{1}$ and $\tau_{c}$ are functions of unknowns including pore pressure and the cohesion (frictional strength) of the pre-existing faults, reasonable assumptions about these parameters lead to $\tau_{c}$ estimates that agree well with values obtained from laboratory experiments simulating crustal conditions. At a depth of $10 \mathrm{~km}$, the analysis indicates that the minimum inherent shear strength of intact crustal rocks must range between 150-450 bars for zero pore pressure and 150-350 bars for hydrostatic pore pressure, whereas the corresponding maximum shear stresses at $10-\mathrm{km}$ depth are $970-1200$ bars for zero pore pressure and $640-770$ bars for hydrostatic pore pressure.
\end{abstract}

\section{INTRODUCTION}

There is presently a vast amount of laboratory data on the brittle deformation properties of individual rocks and minerals. Experiments on frictional sliding at and above moderate confining pressures (roughly 1 kbar and larger) yield remarkably uniform coefficients of static friction independent of the type of fault surface, experimental configuration, or the rock type [Byerlee, 1978]. Field tests in conjunction with in situ stress measurements seem to confirm the laboratory friction values [Raleigh et al., 1977]. Thus it appears that laboratory friction data can be applied to crustal faulting. However, extrapolation of laboratory data on the strength of rock under crustal conditions remains a major unresolved issue. Proper extrapolation requires detailed knowledge of the effects of temperature, pore pressure, and strain rate on strength.

Thus paper describes an investigation of faulting relationships in a unique area in the northern Basin and Range province in which there are clear geologic constraints on the style and timing of deformation. Within this area, it is observed that pre-existing faults have been able to locally accommodate strain by oblique-normal slip whereas regionally favorably oriented-normal faults were breaking through the upper crust. Assuming a uniform stress field throughout the region, stress constraints imposed by utilizing a frictional sliding relationship for these pre-existing faults are compared with stress ratios obtained from a relationship for norml fault equilibrium based on the Coulomb criterion for faulting in intact rock. This analysis allows us to place limits on the inherent shear strength of intact crustal rock (strength at zero pressure) and also on the maximum shear stresses.

\section{Faulting Patterns and Extension Direction}

Accumulating geologic and geophysical data appear to indicate that a simple pattern of displacements is responsible for

This paper is not subject to U.S. copyright. Published in 1980 by the American Geophysical Union.

Paper number 9B1245. extension in the northern Basin and Range province despite the complex pattern of faulting [Zoback and Thompson, 1978]. Figure 1 shows the directions of horizontal extension and least principal stress in the northern Basin and Range. Horizontal extension directions are based on geologic indicators of the sense of fault slip such as fault grooves and slickensides and also on measured displacements from historic earthquakes. Horizontal least principal stress directions are obtained from T-axes of focal plane mechanisms and in situ stress (hydraulic fracturing) measurements. As has been noted previously, the general correspondence of measured extension directions and the focal mechanism $T$-axes suggest that the $T$-axes are reliable indicators of least principal stress directions. The data shown in Figure 1 are tabulated in Table 1 and presented in rose diagrams in Figure 2. The mean extension direction is $\mathrm{N} 62^{\circ} \mathrm{W} \pm 14^{\circ}$ while the mean least principal stress direction inferred from the focal plane mechanisms and in situ stress measurements is $\mathrm{N} 59 \mathrm{~W} \pm 25^{\circ}$. The focal mechanism T-axes are considerably scattered; this scatter may be real arising from slip on preexisting faults or it may be due to poor control and the use of composite solutions. Despite the scatter, a picture of fairly uniform WNW-ESE extension in the northern Basin and Range emerges.

WNW-ESE directed extension is consistent with the overall NNE trend of basins and ranges within the Great Basin (Figure 3). A notable exception to this pattern of faulting is in north-central Nevada where a nearly orthogonal set of normal faults trending NNW and ENE are responsible for the modern ranges. However, measured slip on these faults agrees with the overall pattern of horizontal displacements (some of these slip directions are included in Table 1). A possible interpretation of this orthogonal set of faults is that they represent pre-existing planes of weakness responding to the present stress field. The aeromagnetic map of Nevada indicates a prominent aeromagnetic high in this region of north-central Nevada (see Steward et al. [1975] and inset on Figure 3). This NNW-trending high reflects a zone of graben-filling basalts, 


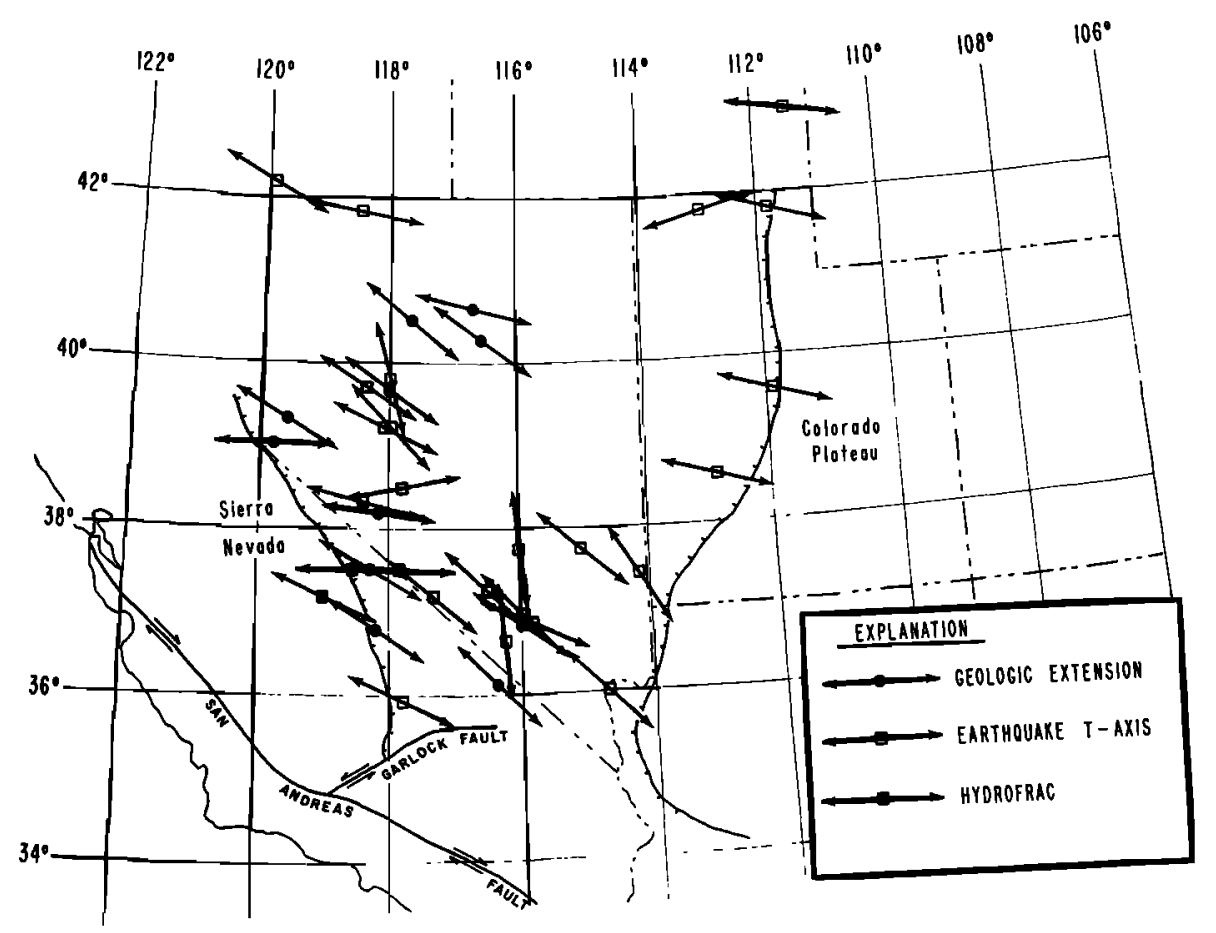

Fig. 1. Extension directions and least principal stress orientations for the northern Basin and Range province.

rhyolites, and NNW-trending dike swarms interpreted as a distinct, 250-km-long rift that formed 17-14 m.y. ago [Stewart et al., 1975; Zoback and Thompson, 1978]. A mid-Miocene WSW-ENE least principal stress direction of broad regional extent may be inferred from the NNW-trending dike swarms in Nevada and parallel contemporaneous feeder dikes for the Columbia River basalts. The $\mathrm{N} 30^{\circ}-35^{\circ} \mathrm{W}$ trending graben of the western Snake River Plain has been interpreted as forming contemporaneously with the eruption of the Columbia River basalts [Mabey, 1976]. This mid-Miocene least principal stress direction differs by roughly $45^{\circ}$ from the modern WNW-ESE extension direction.

Thus, it is clear why the NNW trend should constitute preexisting planes of weakness. A detailed examination of geologic features along the northern Nevada rift zone in the Midas trough region (arrow on Figure 3) suggests an origin for the ENE-trending planes of weakness. A prominent, segmented NNW-trending rhyolite dike associated with the rifting was found in this region. This feature has been previously discussed in detail [Zoback and Thompson, 1978], however, the conclusions are summarized here because they bear directly on early evidence for faulting along the ENE trend. Lack of evidence for faulting outside of the dike segments (Figure 4) as well as the orientation of a small segment between the two major segments support a leaky transform origin for the feature [Zoback and Thompson, 1978]. Recent numerical studies by Fujito and Sleep [1978] predict a reorientation of stresses consistent with the pattern shown in Figure $4 b$ caused by drag along the transform fault. Thus there is an indication that ENE-trending planes of weakness may have developed as transforms during massive dike intrusion in mid-Miocene time. Obviously, the transform faults would be expected to have a $90^{\circ} \mathrm{dip}$ whereas the modern faults have approximately a $60^{\circ} \mathrm{dip}$ at the surface. Thus these postulated ENE-trending transforms are not viewed as major crust-cutting features but rather as a zone of discontinuous planes of weakness that later coalesced to form the modern range-front faults in this region. Alternatively, the ENE trend may represent an earlier zone of weakness, possibly originating during the Precambrian, as suggested by Eaton et al. [1975] for the ENE-trending eastern Snake River Plain-Yellowstone trend.

Referring to the physiographic map (Figure 3), it is apparent that the NNW- and ENE-trending planes of weakness presumed to have developed during mid-Miocene rifting were able to accommodate extension as the least principal stress direction changed $\sim 45^{\circ}$ in a clockwise sense, whereas in the surrounding region major crustal blocks were faulted with an orientation approximately perpendicular to the modern least principal stress direction. The observation that WNW-ESE (modern) extension was accommodated by slip on pre-existing faults of markedly oblique trends in a restricted region in the vicinity of the mid-Miocene rift while new, more favorably oriented NNE-trending faults were being formed in the surrounding region allows us to place limits on the inherent shear strength of the crust and the relative magnitudes of the principal stresses.

\section{THEORY}

To investigate the oblique slip of the ENE-trending faults responsible for most of the modern physiography in northcentral Nevada, regional stresses are resolved on a fault plane where frictional sliding relationships are assumed to apply; this permits calculation of a range of allowable stress states. These values are compared with principal stress ratios obtained from a relationship for normal fault equilibrium based on the Coulomb criterion for faulting in intact rock. This criterion is considered valid because new normal faults were forming in the surrounding region as the rift zone faults continued to slip. 
TABLE 1. Stress Orientations and Extension Directions for the Northern Basin and Range Province

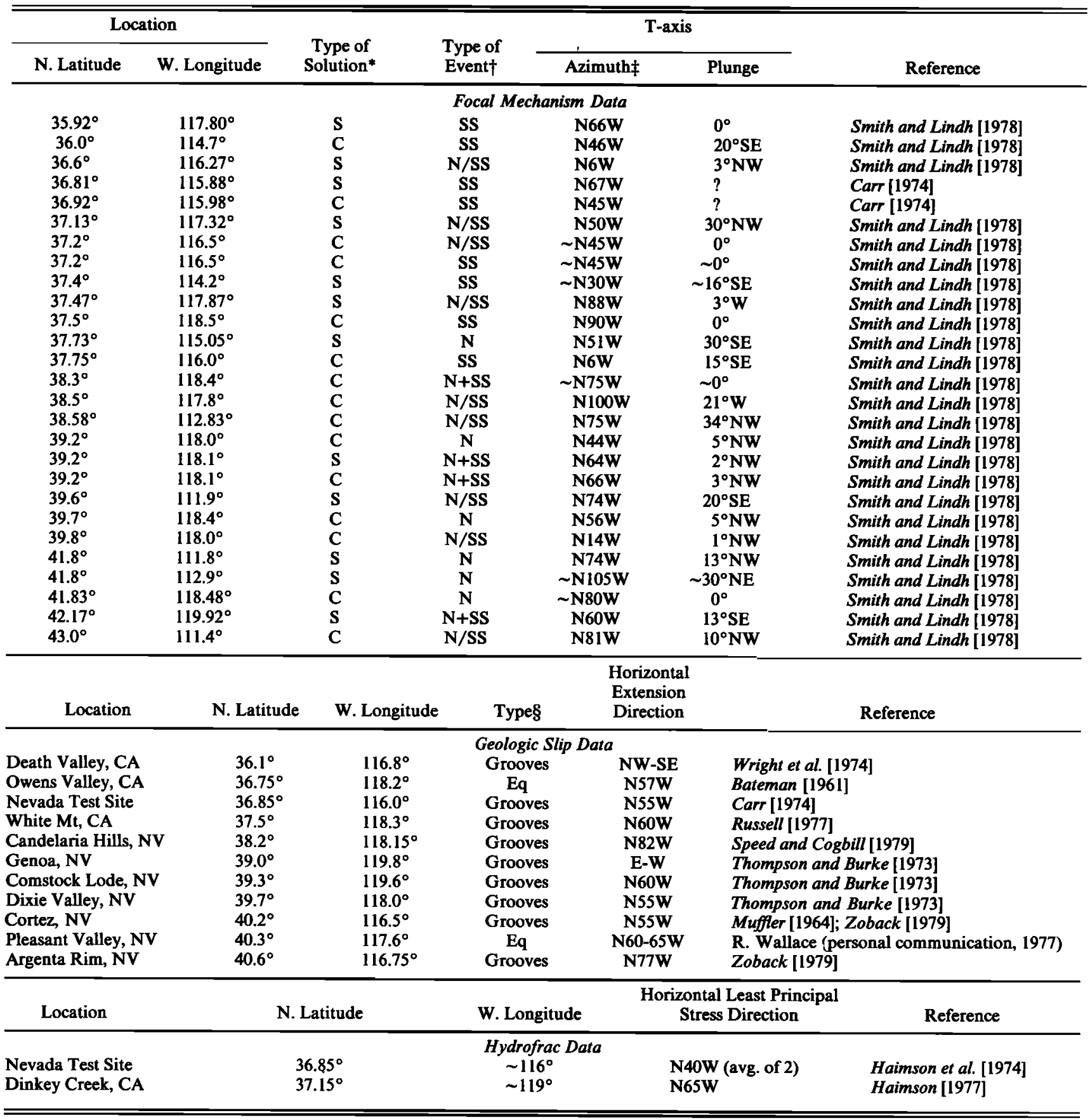

*S, single event solution; $\mathrm{C}$, composite solution.

†N, normal; SS, strike slip, N/SS - predominately normal; N+SS, approximately equal normal and strike-slip movement.

$\ddagger$ Azimuth resolved to NW quadrant.

§Grooves, based on fault grooves and slickensides; Eq, based on historical earthquake offsets.

A tensor transformation can be used to resolve the regional stresses to shear and normal stresses acting in the slip direction on the fault plane. This analysis requires that the orientation of the regional principal stresses, as well as the orientation of the fault plane and slip direction be known. As presented earlier, earthquake focal mechanism T-axes as well as in situ stress measurements suggest an orientation of N60W-S60E for $S_{3}$ (least principal stress). Active normal faulting throughout the province suggests that $S_{1}$ (maximum principal stress) is vertical. Thus, a right-hand coordinate system requires that $S_{2}$ be horizontal and be in a $S 30^{\circ} \mathrm{W}$ direc- tion ( $S_{1}$ vertical, positive down and $S_{3}$ horizontal, N60 ${ }^{\circ} \mathrm{W}$ ).

The generally NNE-trending faults which characterize the Nevada Basin and Range change abruptly to NE to ENE trends in the vicinity of the mid-Miocene rift. (We have assumed that slip on these faults will occur such that the horizontal component of slip is in the least principal stress direction.) Using an average trend of $\mathrm{N} 65^{\circ} \mathrm{E}$ for these modern faults and a dip of $60^{\circ}$ (dips of $60-65^{\circ}$ are commonly observed on Basin and Range normal faults [Thompson, 1959]) as representative of the cross-faulting trend, the slip direction has an azimuth of $\mathrm{N} 60^{\circ} \mathrm{W}$ and a plunge of $55^{\circ} \mathrm{NW}$. 


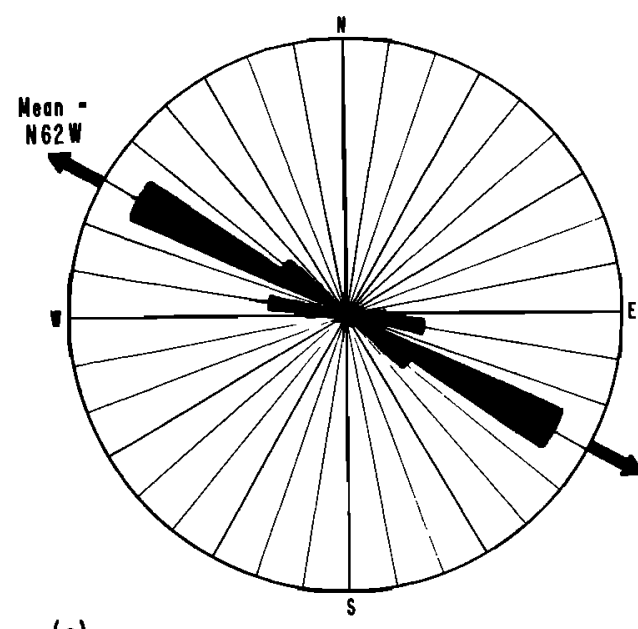

(0)

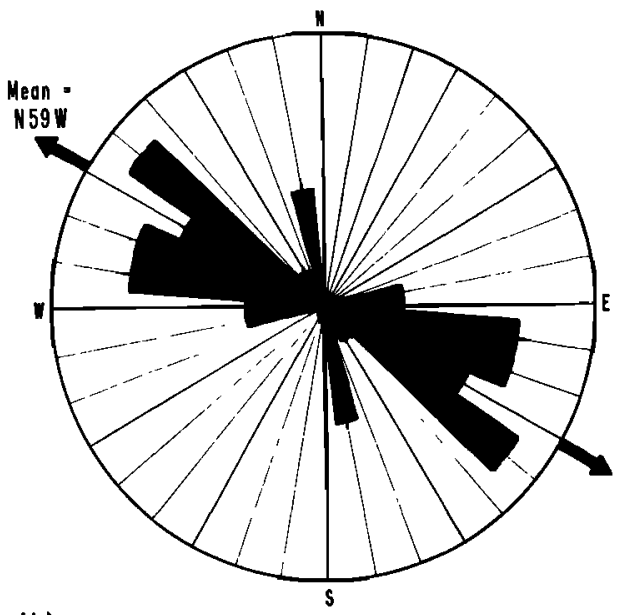

(b)

Fig. 2. Rose diagrams for data presented in Figure 1. (a) extension directions determined from geologic evidence; (b) focal mechanism $T$-axes and in situ stress data.

The fault plane coordinate system is defined with the normal to the fault and the slip direction in the fault as the coordinate axes $x_{1}{ }^{\prime}$ and $x_{2}{ }^{\prime}$, respectively, and the normal to the slip direction in the fault plane as $x_{3}{ }^{\prime}$. Rotation of the principal stresses $S_{y}$ (which define the unprimed coordinate system) to the new coordinate system is accomplished by a tensor transformation:

$$
S_{k i}{ }^{\prime}=a_{k} a_{l j} S_{l j}
$$

The direction cosine matrix $a_{i j}$ for the transformation can be determined from angles between the coordinate axes measured on an equal area projection (Figure 5).

\begin{tabular}{clll}
\multicolumn{1}{c}{} & \multicolumn{1}{c}{$x_{1}$} & $x_{2}$ & \multicolumn{1}{c}{$x_{3}$} \\
\cline { 2 - 4 }$x_{1}{ }^{\prime}$ & $\cos 120^{\circ}$ & $\cos 121^{\circ}$ & $\cos 45^{\circ}$ \\
$x_{2}{ }^{\prime}$ & $\cos 37^{\circ}$ & $\cos 90^{\circ}$ & $\cos 53^{\circ}$ \\
$x_{3}{ }^{\prime}$ & $\cos 107.5^{\circ}$ & $\cos 31^{\circ}$ & $\cos 65.5^{\circ}$
\end{tabular}

The normal stress across the fault plane $\left(S_{N}\right)$ is given by

$$
\begin{gathered}
S_{N}=S_{11}^{\prime}=a_{11}{ }^{2} S_{1}+a_{12}{ }^{2} S_{2}+a_{13}{ }^{2} S_{3} \\
S_{N}=0.25 S_{1}+0.27 S_{2}+0.50 S_{3}
\end{gathered}
$$

The shear stress $(\tau)$ along the slip direction is given by

$$
\begin{gathered}
\tau=-S_{12}{ }^{\prime}=a_{11} a_{21} S_{1}+a_{12} a_{22} S_{2}+a_{13} a_{23} S_{3} \\
\tau=0.40 S_{1}-0.43 S_{3}
\end{gathered}
$$

These equations can be combined with the linear law for frictional sliding pre-existing faults [Jaeger, 1962, p. 76]:

$$
\tau=S_{0}+\mu_{f}\left(S_{N}-P\right)
$$

where $S_{0}$ is cohesion (strength on pre-existing faults due to a healing mechanism), $P$ is pore pressure, and $\mu_{f}$ is the coefficient of friction for frictional sliding. Substituting (1) and (2) into (3), we can solve for slip on the ENE-trending faults:

$$
\begin{aligned}
S_{0}-\mu_{f} P+\left(0.25 \mu_{f}-0.40\right) S_{1} & +\left(0.27 \mu_{f}\right) S_{2} \\
& +\left(0.50 \mu_{f}+0.43\right) S_{3}=0
\end{aligned}
$$

This equation can be solved for $S_{3} / S_{1}$ (the ratio of the least principal stress to the maximum principal stress) as a function of $P, S_{0}, S_{1}$, and $\mu_{f}$ with the bounds $S_{1}=S_{2}$ and $S_{2}=S_{3}$ :

$$
S_{3} / S_{1}=\frac{\mu_{f} P-S_{0}-S_{1}\left(0.52 \mu_{f}-0.40\right)}{S_{1}\left(0.50 \mu_{f}+0.43\right)} \quad S_{2}=S_{1}
$$

and

$$
S_{3} / S_{1}=\frac{\mu_{f} P-S_{0}-S_{1}\left(0.25 \mu_{f}-0.40\right)}{S_{1}\left(0.77 \mu_{f}+0.43\right)} \quad S_{2}=S
$$

Frictional sliding on pre-existing fault planes has been the subject of numerous laboratory investigations. Byerlee [1978] summarizes these data and suggests that for normal stresses up to $\mathbf{2} \mathrm{kbar}$ the shear stress required to cause sliding on preexisting faults is given approximately by

$$
\tau=0.85 \sigma_{N}
$$

In this case, $S_{0}=0$ and $\mu_{f}=0.85$. For normal stresses above 2 kbar the shear stress for frictional sliding is given approximately by

$$
\tau=0.5+0.6 \sigma_{N} \quad \mathrm{kbar}
$$

where $S_{0}=500$ bars and $\mu_{f}=0.6$. However, the linear relation $\tau=0.67 \sigma_{N}$, with $S_{0}=0$, appears to fit the data equally well in the 2-13 kbar range.

Byerlee [1978] concludes that these frictional coefficients $\left(\mu_{f}\right.$ $=\mathbf{0 . 8 5}$ for low normal stress i.e., less than about $\mathbf{2} \mathrm{kbar}$, and $\boldsymbol{\mu}_{f}$ $=0.6-0.67$ for normal stresses greater than 2 kbar) are valid regardless of the type of fault surface, the rock type (with the possible exception of montmorillonite gouge), or the experimental configuration. His data also limit the cohesive strength $\left(S_{0}\right)$ on pre-existing faults between 0 and 500 bars. Accordingly, we have chosen $0.6-0.8$ as a reasonable range for $\mu_{f}$ and have allowed $S_{0}$ to vary between 0 and 500 bars.

The corresponding range of $S_{3} / S_{1}$ calculated by $(5 a)$ and (5b) can be compared with $S_{3} / S_{1}$ values for normal fault equilibrium based on the Coulomb criterion [Jaeger and Cook, 1969]. Such a comparison is justified because normal faults in the surrounding region were formed striking perpendicular to the least principal stress direction as the rift faults continued to slip.

According to the Coulomb theory, faulting in intact rock 


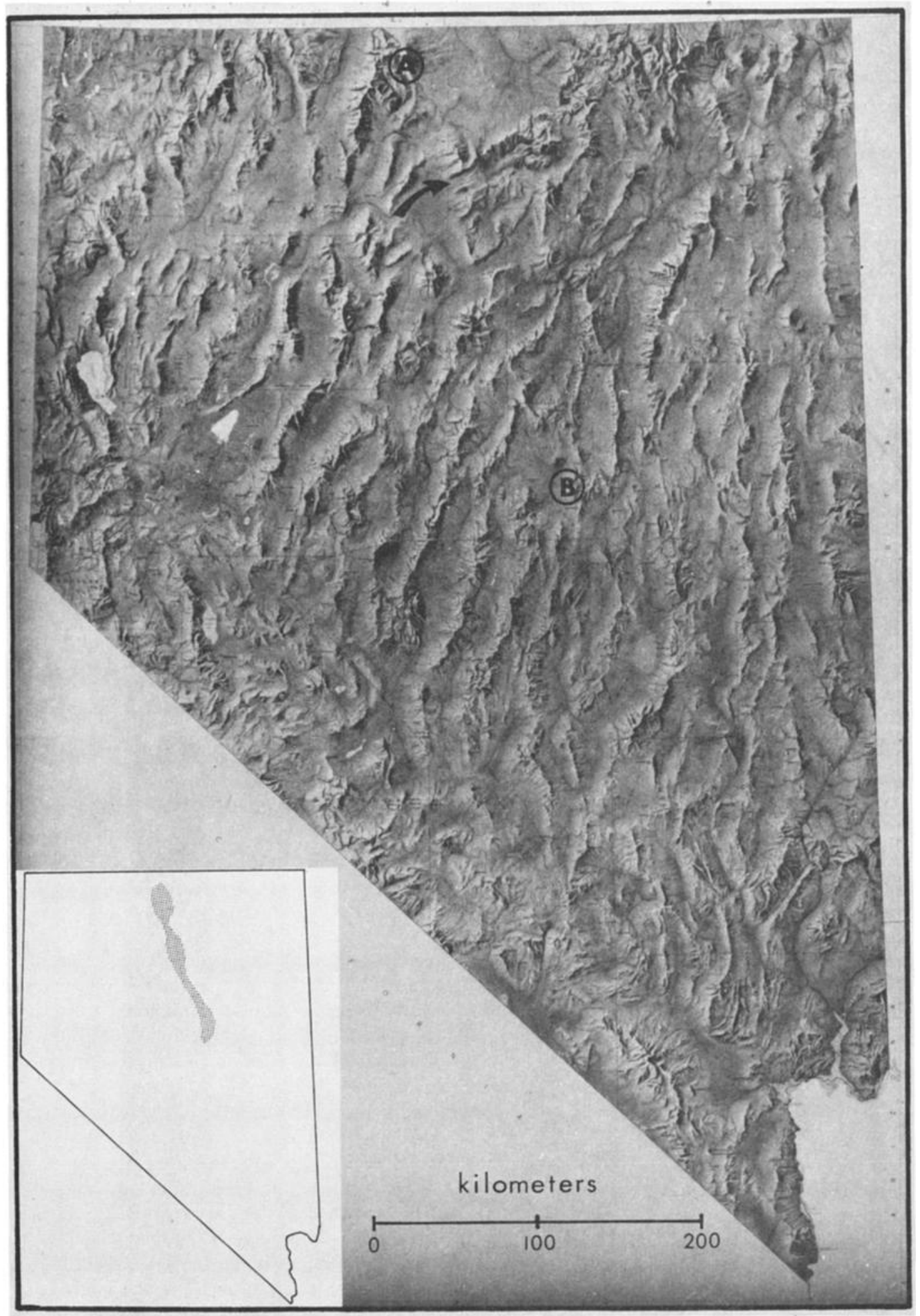

Fig. 3. Physiographic map of Nevada. Letters A and B mark the extent of the mid-Miocene rift. Location of Sawtooth dike/Midas trough area is indicated by the arrow. Inset indicates outline of aeromagnetic high associated with the rift.

occurs when the Mohr circle describing the state of stress is tangent to a linear failure envelope. In this case $\tau_{c}$ is the inherent shear strength of intact crustal rocks (strength at zero pressure), $\sigma_{N}$ is effective stress $\left(S_{N}-P\right), \theta$ is the dip of the fault, and $\phi$ is the angle of internal friction. The failure envelope is given by
Defining $\mu_{i}=\tan \phi$, where $\mu_{i}$ is the coefficient of internal friction, $\mu_{i}$ is thus related to $\theta$, the dip of the fault, since $\phi=2 \theta-$ $\pi / 2$. The Coulomb criterion for shear failure in intact rock [Jaeger and Cook, 1969, p. 93, equation 2] can be written in terms of the principal stresses as

$$
\tau=\tau_{c}+\sigma_{N} \tan \phi
$$$$
1 / 2\left(\sigma_{1}-\sigma_{3}\right)=1 / 2\left(\sigma_{1}+\sigma_{3}\right) \sin \phi+\tau_{c} \cos \phi
$$ 


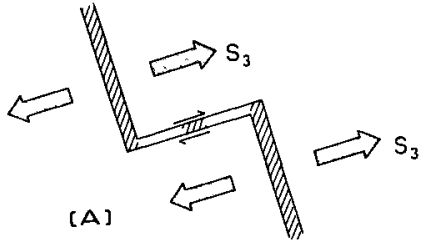

WIIIII occupied by dike

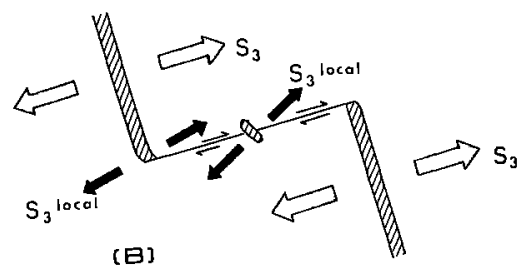

Fig. 4. Diagrammatic maps showing postulated stress regime at the time of intrusion of Sawtooth dike (mid-Miocene). (a) 'Leaky transform' origin; (b) local reorientation of stress field resulting from shear along the transform fault.

where $1 / 2\left(\sigma_{1}-\sigma_{3}\right)$ is the maximum shear stress, $1 / 2\left(\sigma_{1}+\sigma_{3}\right)$ is the mean stress in the $\sigma_{1}, \sigma_{3}$ plane, and $\tau_{c}$ is the inherent shear strength of the material. Substituting these values into (6) and replacing $\sigma$ with effective stress $(S-P)$ yields

$$
S_{3} / S_{1}=\frac{1}{1+\sin \phi}\left[1-\sin \phi+\frac{2 P}{S_{1}} \sin \phi+\frac{2 \tau_{c}}{S_{1}} \cos \phi\right]
$$

Thus we can solve (7) as a function of $\tau_{c}, P$, and $\phi$ for given values of $S_{1}$.

Common dips on Basin and Range normal faults that have not been tilted or are tilted only slightly are $60^{\circ}-65^{\circ}$ [Thompson, 1959]. While there is growing evidence that listric normal faulting may locally be important in the Basin and Range, the small tilts $\left(6^{\circ}-8^{\circ}\right)$ of $15-16$ m.y. basalt flows capping the ranges in the vicinity of the mid-Miocene rift appear to preclude large rotations resulting from slip on listric faults. Thus the major range-bounding faults in this region are considered to be steep, relatively planar faults with dips of $60^{\circ}-65^{\circ}$ (the range of measured surface dips). This dip range corresponds to a $\mu_{\text {s }}$ between 0.57 and 0.84 . This range is essentially the

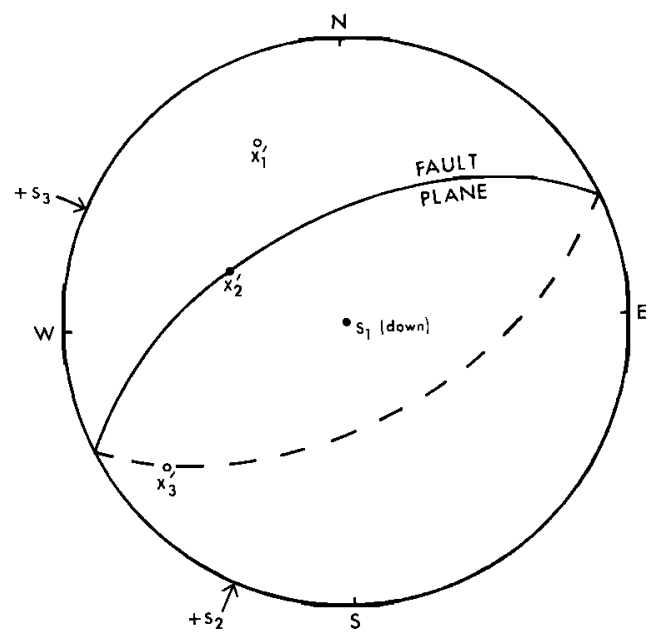

Fig. 5. Equal-area projection showing orientations of the principal stresses and the fault plane coordinate system (primed) described in the text. Solid circles denote lower hemisphere points, open circles denote upper hemisphere points. same as the range of $\mu_{f}$, the coefficient of friction for frictional sliding. Thus in order to reduce the number of variables we assume that $\mu_{t}=\mu_{f} \equiv \mu$. Within the range of $\mu$ to be considered in the analysis, experimental results appear to support this assumption [see Handin, 1969].

\section{RESULTS}

Figures 6 and 7 plot $S_{3} / S_{1}$ as a function of $\mu$, the coefficient of friction, at a depth of $10 \mathrm{~km}\left(S_{3} / S_{1}\right.$ values for normal fault equilibrium are a function of $S_{1}$, hence are depth dependent). A depth of $10 \mathrm{~km}$ was used since most Basin and Range earthquakes fall in the depth range of 5-15 km [Smith and Sbar, 1974], although the depth estimates are poorly constrained. Two cases are considered, zero pore pressure and hydrostatic pore pressure. In all cases slip will not occur on the ENEtrending faults unless their cohesive strength $\left(S_{0}\right)$ is less than $\tau_{c}$, the inherent shear strength of intact crustal rock; that is, these ENE-trending faults must be pre-existing planes of weakness. The range of possible stress states calculated from the linear frictional sliding law for slip on the ENE faults (4) is given by the ruled region. The solid lines denote normal fault equilibrium for various values of $\tau_{c}$ for intact crustal rock based on the Coulomb criteria (6). These values represent a lower limit for $S_{3} / S_{1}$. Smaller values (which correspond to higher shear stresses) are not possible, because faulting occurs when the shear stress $1 / 2\left(S_{1}-S_{3}\right)$ exceeds the equilibrium value. The heavy solid bar represents the range of reasonable values of $\mu, 0.6-0.8$.

An important additional constraint can be placed on the above analysis for cases with pore pressure. For shear failure to occur, the least principal stress $\left(S_{3}\right)$ must be larger than the pore pressure; if not, the pore pressure would hydro-frac the rock along vertical fractures striking perpendicular to $S_{3}$. Thus in the hydrostatic pore pressure case (Figure 7 ), $S_{3}$ cannot be less than the hydrostatic head $\rho_{w} g z$, where $\rho_{w}$ is the density of water $\left(1 \mathrm{~g} / \mathrm{cm}^{3}\right), g$ is gravity, and $z$ is depth. The greatest principal stress, $S_{1}$, however, has been assumed equal to the lithostatic load, $\rho_{r} g z$, where $\rho_{r}$ is the density of crustal rock $\left(\sim 2.7 \mathrm{~g} / \mathrm{cm}^{3}\right)$; thus a minimum value for $S_{3} / S_{1}$ under hydrostatic pore pressure conditions is 0.37 . The shaded line indicates this level on Figure 7. Note that the constraint that $S_{3}$ $>P$ limits cohesion $\left(S_{0}\right)$ on the pre-existing faults to a maximum value of $\mathbf{3 0 0}$ bars for the hydrostatic case. The value of $S_{0}=500$ bars for cohesion suggested by laboratory frictional sliding experiments above 2 kbar confining pressure [Byerlee, 1978] appears to be too large. Obviously, this rationale cannot be applied to the zero pore pressure case (Figure 6).

It should also be noted that the actual state of stress in the Basin and Range should be closer to the lower limit of the ruled region, when $S_{2}=S_{1}$. If the intermediate stress were very low $\left(S_{2} \simeq S_{3}\right)$ we would not expect the uniform NNESSW fault pattern observed, i.e., faults could open in either the $S_{2}$ or the $S_{3}$ direction. Consistent with the idea that $S_{2} \approx$ $S_{1}$, earthquake focal mechanisms in the northern Basin and Range yield both normal and strike-slip solutions (as indicated in Table 1) with similar T-axes [see also Hamilton et al., 1969]. The strike-slip mechanisms are most common along the western margin of the northern Basin and Range.

By comparing the range of allowable stress states (determined from ( $5 a)$ and $(5 b)$ ) with normal fault equilibrium values, some limits on the inherent shear strength of intact crustal rocks, $\tau_{c}$, can be obtained. Laboratory data on the shear 

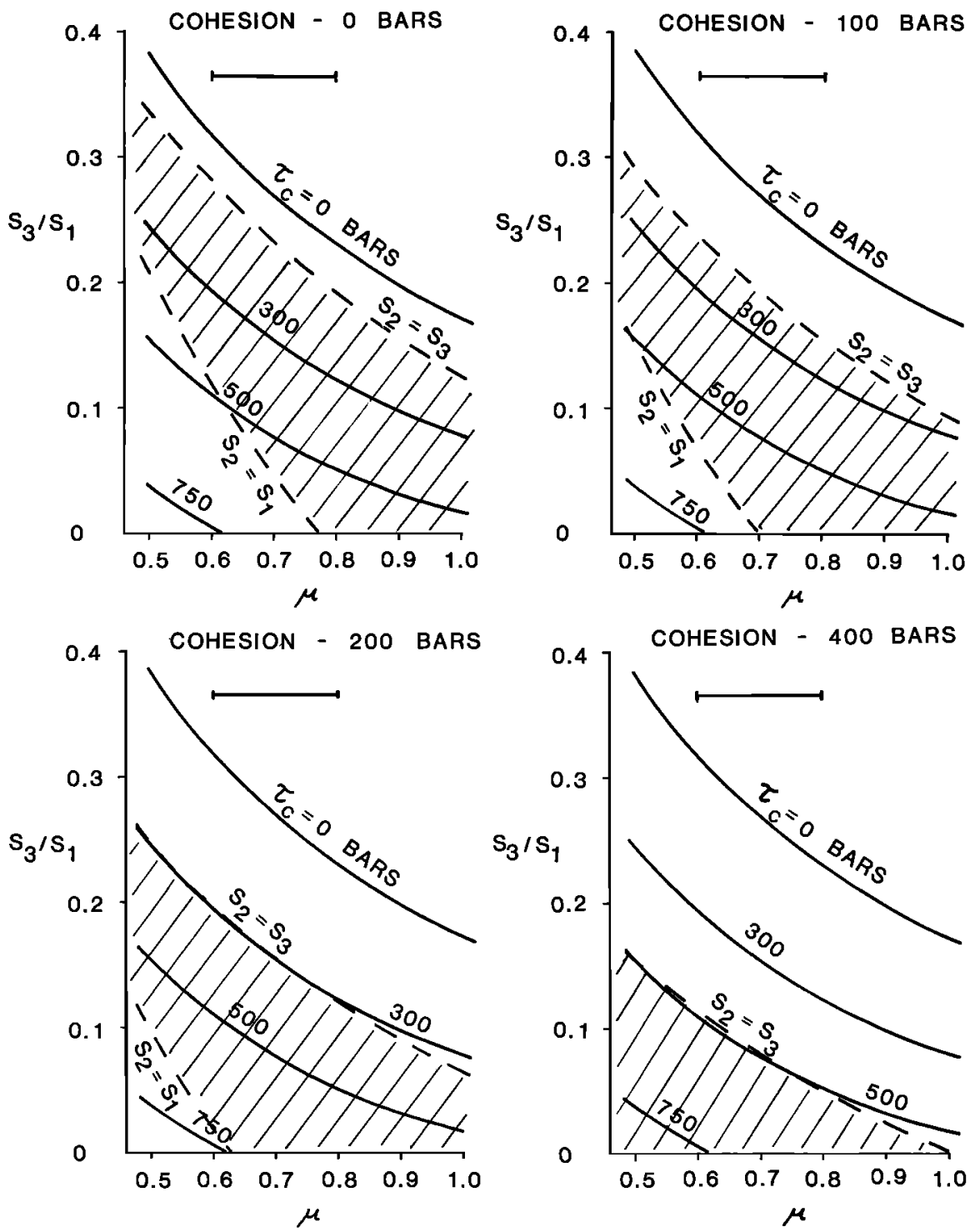

Fig. 6. Ratio of greatest to least principal stress $\left(S_{3} / S_{1}\right)$ versus coefficient of friction, $\mu$, for zero pore pressure and for various values of cohesion on the pre-existing faults. The heavy solid lines represent normal fault equilibrium for various values of $\tau_{c}$, inherent strength of intact crustal rock (7). Ruled region gives range of allowable stress states bound by the dotted lines determined from $(5 a)$ and $(5 b)$. The heavy bar gives the range of reasonable values of $\mu, 0.6-0.8$.

strength of intact rock samples vary widely. Handin [1966] summarizes strength data and concludes that the $\tau_{c}$ of intact material is of the order of 100-200 bars for sedimentary rocks and about 500 bars for crystalline rocks. However, Byerlee [1971] reported a shear strength of 700 bars for intact Weber B sandstone and a shear strength on the order of $1 \mathrm{kbar}$ for Westerly Granite [Byerlee, 1967]. Our results, summarized in Table 2 , generally support these laboratory data and indicate that inherent shear strength of intact crustal rock, $\tau_{c}$, is between 150 and 600 bars for zero pore pressure and between 150 and 400 bars for hydrostatic pore pressure. The upper limit for $\tau_{c}$ in the hydrostatic case is provided by the constraint that $S_{3}$ must be greater than $P$.

'Maximum' shear stress $\left(1 / 2\left(S_{1}-S_{3}\right)\right)$ can also be determined from the calculated range of allowable stress states. We have done this for $\mu=0.6$ corresponding to a favorably oriented normal fault with a $60^{\circ}$ dip and a coefficient of frictional sliding of 0.6 (as suggested by Byerlee [1978] for conditions at a $10-\mathrm{km}$ depth). These values are also given in Table
2. As the cohesion on the ENE faults increases, the values of $\tau_{c}$ also increase as expected; in addition, the effect of introducing pore pressure tends to reduce the values of shear stress, that is, to increase $S_{3} / S_{1}$. Since, as suggested above, the actual state of stress must be closer to $S_{2}=S_{1}$ than $S_{2}=S_{3}$, the higher magnitude end of the ranges of both strength and shear stress are preferred. The actual upper limit for shear stress in the hydrostatic case is provided by the constraint that $S_{3}>P$ which leads to a minimum allowable value of $S_{3} / S_{1}=$ 0.37 and a maximum sheer stress $\left(1 / 2\left(S_{1}-S_{3}\right)\right)$ of 850 bars at 10-km depth.

In situ measurements of the magnitudes of $S_{1}$ and $S_{3}$ have provided numerous values for 'maximum' shear stress $\left(1 / 2\left(S_{1}\right.\right.$ $\left.-S_{3}\right)$ ) to depths of $2-2.5 \mathrm{~km}$ with a few values down to $5 \mathrm{~km}$ [see McGarr and Gay, 1978]. These results indicate shear stresses between 100 and 275 bars at 2-2.5 km depths. Maximum shear stress at $2.25-\mathrm{km}$ depth predicted by the present analysis ranges between 215 and 305 bars for zero pore pressure and from 135 to 190 bars for hydrostatic pore pressure. 

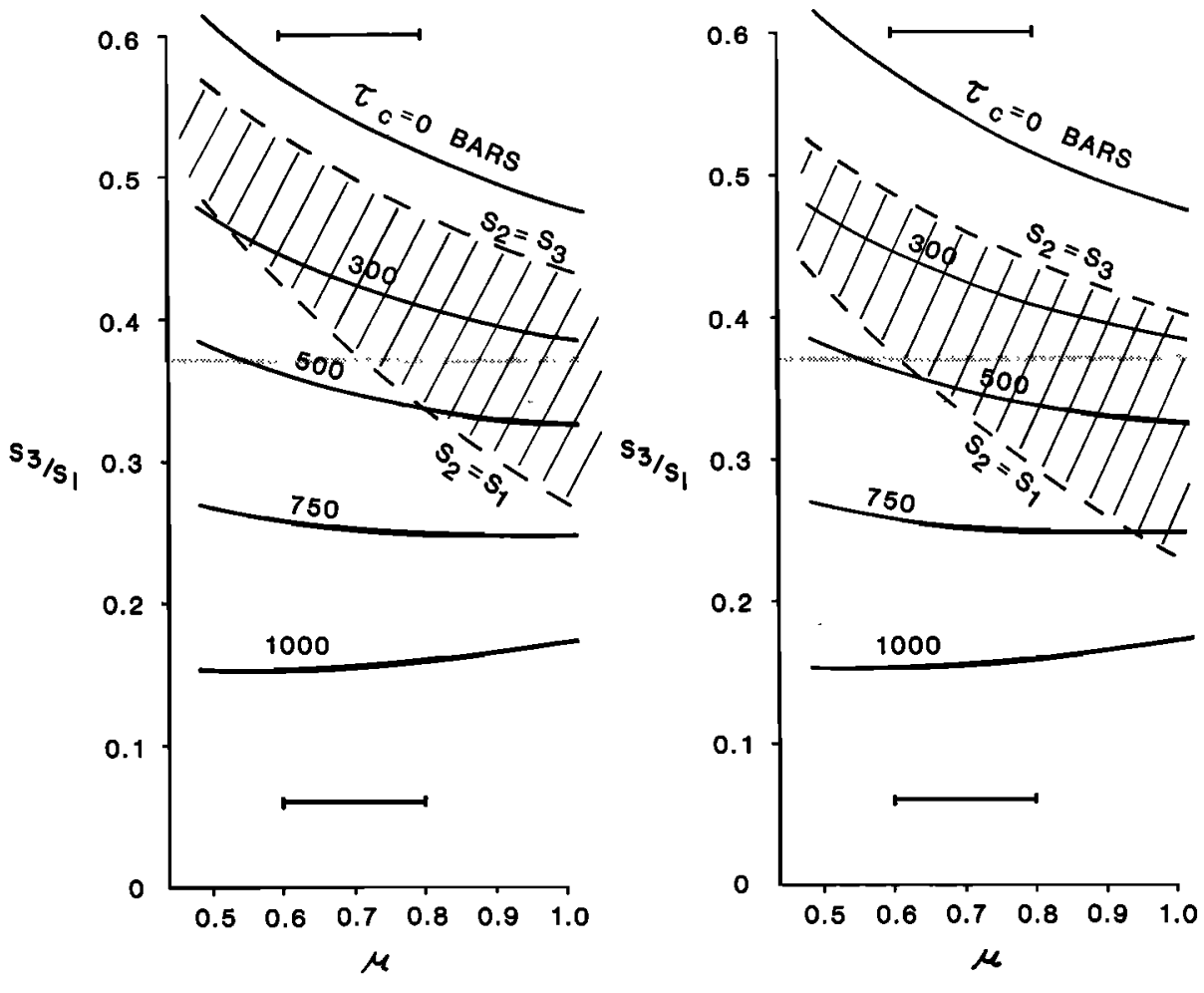

COHESION - 300 BARS

COHESION - 500 BARS
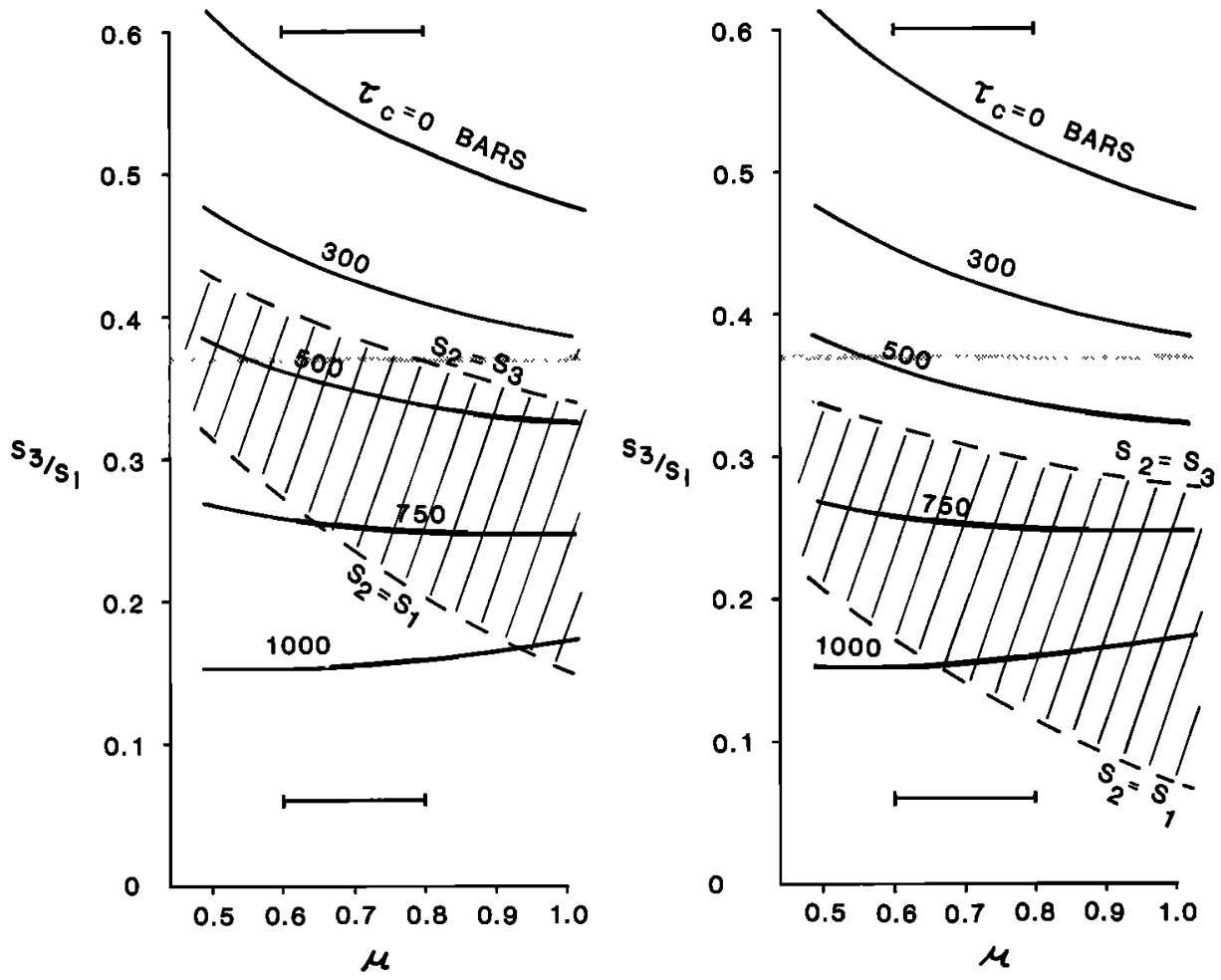

Fig. 7. Ratio of greatest to least principal stress $\left(S_{3} / S_{1}\right)$ versus coefficient of friction, $\mu$, for hydrostatic pore pressure and for various values of cohesion on the pre-existing faults. The lightly shaded line marks the minimum allowable level of $S_{3} / S_{1}$ determined by the requirement, for shear failure, that $S_{3}$ must be greater than the pore pressure. Other designations the same as in Figure 6. 
TABLE 2. Results of Analysis

\begin{tabular}{ccccc}
\hline & $\begin{array}{c}\text { Assumed } \\
\text { Cohesion } \\
\text { on ENE } \\
\text { Faults }\left(S_{0}\right), \\
\text { bars }\end{array}$ & $\begin{array}{c}\text { Inherent } \\
\text { Crustal Shear } \\
\text { Strength }\left(\tau_{c}\right), \\
\text { bars }\end{array}$ & $\begin{array}{c}\text { 'Maximum' } \\
\text { Crustal Shear } \\
\text { Stress } 1 / 2\left(S_{1}-S_{3}\right), \\
\text { bars }\end{array}$ & $\begin{array}{c}\text { Magnitude, } \\
S_{0} / \tau_{c}\end{array}$ \\
\hline 0 & 0 & $150-450$ & $970-1200$ & 0 \\
Hydrostatic & 0 & $150-350$ & $640-770$ & 0 \\
0 & 100 & $250-550$ & $1025-1250$ & $0.40-0.18$ \\
Hydrostatic & 100 & $250-400$ & $690-840$ & $0.40-0.25$ \\
0 & 200 & $350-650$ & $1080-1325$ & $0.57-0.30$ \\
Hydrostatic & 300 & $\simeq 400$ & $800-850$ & 0.75 \\
0 & 400 & $550-750$ & $1200-1350$ & $0.73-0.53$ \\
Hydrostatic & 500 & impossible, $S_{3}<P$ & \\
\hline
\end{tabular}

Depth $=10 \mathrm{~km}$ and $S_{1}=\rho g h=2.7 \mathrm{kbars}$.

\section{DISCUSSION}

The analysis described above makes two primary assumptions: (1) a uniform stress field throughout northern Nevada and (2) continuing slip on preexisting faults in the vicinity of a mid-Miocene rift while regionally major crustal blocks were being broken by favorably oriented normal faults. The assumed uniformity of the principal stress field appears to be a critical assumption; however, the inferred range of crustal strength estimates is only mildy dependent on the stress orientation. Changing the least principal stress orientation $\pm 5^{\circ}$ only changes the range of possible strengths $10-20 \%$.

Alternatively, it could be proposed that a local variation in $S_{3}$ direction may be the explanation for the anomalous NNWENE pattern of faulting in north-central Nevada. We consider this unlikely because the region where the NNW-ENE trending faulting predominates is a narrow zone, and standard NNE-trending normal faults can be found on either side of it (Figure 3). Thus any variation in principal stress direction would have to be an abrupt and narrow departure from the regional orientation. A second possible explanation for the observed fault patterns in north-central Nevada is a lower inherent cohesion or friction of the crust in the vicinity of the mid-Miocene rift. This, too, we consider unlikely because the only known anomalous deep structure associated with the rift, the dike swarms described previously, is restricted to a $5 \mathbf{~ k m}$ wide, NNW-trending zone which is probably only $25-33 \%$ dike.

Thus, it appears that extensional strain in a restricted region of north-central Nevada has continually been accomplished by oblique slip on pre-existing faults. The cohesive strength of these faults was therefore low enough to permit continued slip, obviating the formation of new, favorably oriented normal faults in this region despite a roughly $45^{\circ}$ clockwise change in least principal stress orientation probably in late Miocene time [Zoback and Thompson, 1978].

\section{Conclusions}

In summary, we have placed limits on crustal shear stress and the inherent shear strength of intact crustal rocks by assuming continued slip along pre-existing faults in north-central Nevada while uniform NNE-trending normal faulting was occurring regionally throughout the northern Basin and Range. The pre-existing faults, a nearly orthogonal set trending NNW and ENE, are thought to have developed in midMiocene time along a 250-km-long, NNW-trending rift zone; however, most of the modern basins and ranges trend NNE. This change in fault trend is believed to have resulted from a roughly $45^{\circ}$ clockwise change in the least principal stress direction since the formation of the rift, probably between 15 and $6 \mathrm{~m} . \mathrm{y}$. B.P. [Zoback and Thompson, 1978].

Geologic and geophysical data on extension and least principal stress directions are used to infer the orientation of a principal stress field. This assumed uniform stress field is utilized in simple, two-dimensional faulting theory to constrain the ratio of the greatest principal to the least principal stress $\left(S_{3} / S_{1}\right)$ as well as the inherent strength of intact crustal rocks $\left(\tau_{c}\right)$. In addition, maximum shear stresses $\left(1 / 2\left(S_{1}-S_{3}\right)\right)$ are computed from the calculated allowable range $S_{3} / S_{1}$. Both parameters, $S_{3} / S_{1}$ and $\tau_{c}$, are functions of the pore pressure and the assumed cohesion (frictional strength) of the preexisting faults.

An important additional constraint for cases with pore pressure is provided by the requirement for shear failure that the pore pressure (P) cannot exceed the least principal stress $\left(S_{3}\right)$. If $\boldsymbol{P}$ did exceed $S_{3}$, failure would occur by hydrofracture of vertical planes striking perpendicular to $S_{3}$. An analysis at 10 km depths indicates that the minimum strength of intact crustal rocks (i.e., when cohesion on pre-existing fault equals zero) must range between $150-450$ bars for zero pore pressure and 150-350 bars for hydrostatic pore pressure, whereas the corresponding maximum shear stresses at $10-\mathrm{km}$ depths are 970 1200 bars for zero pore pressure and 640-770 bars for hydrostatic pore pressure. By allowing a finite amount cohesion on the pre-existing faults $\tau_{c}$, the strength of intact rock, can increase to as much as 750 bars for zero pore pressure (with a maximum cohesion on the pre-existing faults of 400 bars) and to approximately 400 bars for hydrostatic pore pressure (with a maximum allowable cohesion of 500 bars). The upper limit of cohesion on the preexisting faults in the hydrostatic case is provided by the constraint on $S_{3} / S_{1}$ imposed by the requirement that $S_{3}$ be greater than $P$.

The results of the analysis agree well with the range of values obtained from laboratory experiments simulating crustal conditions. In the case of the present analysis, the computed inherent strengths and state of stress are relatively insensitive to the assumed pore pressure distribution. Hence, these results suggest that parameters difficult to account for in laboratory experiments, such as temperature, strain rate, and sometimes even pore pressure, may not be critically important in predicting failure of rock.

Acknowledgments. We thank Amos Nur, George A. Thompson, and Arthur $\mathrm{H}$. Lachenbruch for useful comments and discussion; also, Barry Raleigh, Art McGarr, and Robert O. Burford for critically reviewing the manuscript. This study was in part funded by National Science Foundation grant EAR75-22505. 


\section{REFERENCES}

Bateman, P. C., Willard D. Johnson and the strike-slip component of fault movement in the Owens Valley, California, earthquake of 1872, Bull. Seismol. Soc. Amer., 51, 483-493, 1961.

Byerlee, J. D., Frictional characteristics of granite under high confining pressure, J. Geophys. Res., 72, 3639-3648, 1967.

Byerlee, J. D., The mechanical behavior of Weber sandstone (abstract), Eos Trans. $A G U, 52,343,1971$.

Byerlee, J. D., Friction of rocks, Pure Appl. Geophys., 116, 615-626, 1978.

Carr, W. J., Summary of tectonic and structural evidence for stress orientation at the Nevada Test Site, U.S. Geol. Surv. Open File Rep., 74-176, 53 pp., 1974.

Eaton, G. P., R. L. Christiansen, H. M. Iyer, A. M. Pitt, D. R. Mabey, H. R. Blank, Jr., and M. E. Gettings, Magma beneath Yellowstone Park, Science, 188, 787-796, 1975.

Fujita, K., and N. H. Sleep, Membrane stresses near mid-ocean ridge transform intersections, Tectonophysics, 50, 207-221, 1978.

Haimson, B. C., Crustal stress in the continental United States as derived from hydrofracturing tests, in The Earth's Crust, Geophys. Monogr. Ser., vol. 20, edited by J. G. Heacock, pp. 576-592, AGU, Washington, D. C., 1977.

Haimson, B. C., J. Lacomb, A. H. Jones, and S. J. Green, Deep stress measurements in tuff at the Nevada Test Site, in Advances in Rock Mechanics, vol. II a, pp. 557-561, National Academy of Sciences, Washington, D. C., 1974.

Hamilton, R. M., F. A. McKeown, and J. H. Healy, Seismic activity and faulting associated with a large underground nuclear explosion, Science, 166, 601-604, 1969.

Handin, J., Strength and ductility, in Handbook of Physical Constants, edited by S. P. Clark, pp. 223-289, Geological Society of America, New York, 1966.

Handin, J., On the Coulomb-Mohr failure criterion, J. Geophys. Res., $72,5343-5348,1969$.

Jaeger, J. C., and N. G. W. Cook, Fundamentals of Rock Mechanics, 515 pp., Methuen, London, 1969.

Mabey, D. R., Interpretation of a gravity profile across the Western Snake River Plain, Idaho, Geology, 4, 53-55, 1976.

McGarr, A., and N. C. Gay, State of stress in the earth's crust, $A n n$. Rev. Earth Planet. Sci., 6, 405-436, 1978.
Muffler, L. J. P., Geology of the Frenchie Creek quadrangle, northcentral Nevada, U.S. Geol. Survey. Bull, ,1179, 99 pp., 1964.

Raleigh, C. B., A. McGarr, and M. D. Zoback, Hydraulic fracture gradients, normal faulting, and $\mu$, Eos Trans. AGU 58, 1227, 1977. 1977.

Russell, B. J., A structural break and kinematics of faulting in the White Mountains, California (abstract), Geol. Soc. Amer. Abstr. Programs, 9, 491, 1977.

Smith, R. B., and A. G. Lindh, A compilation of fault plane solutions of the western United States, in Cenozoic Tectonics and Regional Geophysics of the Western U.S., edited by R. B. Smith and G. P. Eaton, Geol. Soc. Amer. Mem., 152, 107-109, 1978.

Smith, R. B., and M. Sbar, Contemporary tectonics and seismicity of the western United States with emphasis on the Intermountain Seismic Belt, Geol. Soc. Amer. Bull., 85, 1205-1218, 1974.

Speed, R. C., and A. H. Cogbill, Candelaria and other left-oblique slip faults of the Candelaria region, Western Great Basin, Geol. Soc. Amer. Bull., 90, 149-163, 1979.

Stewart, J. H., G. W. Walker, and F. J. Kleinhampl, Oregon-Nevada lineament, Geology, 3, 265-268, 1975.

Thompson, G. A., Gravity measurements between Hazen and Austin, Nevada, a study of Basin and Range structure, J. Geophys. Res., 64, 217-230, 1959.

Thompson, G. A., and D. B. Burke, Rate and direction of spreading in Dixie Valley, Basin and Range province, Nevada, Geol. Soc. Amer. Bull., 84, 627-632, 1973.

Wright, L. A., J. K. Otton, and B. W. Troxel, Turtleback surfaces of Death Valley viewed as phenomena of extensional tectonics, Geology, 2, 53-54, 1974.

Zoback, M. L., Direction and amount of Late Cenozoic extension in north-central Nevada (abstract), Geol. Soc. Amer. Abstr. Programs (Cordilleran Sect.), 11, 137, 1979.

Zoback, M. L., and G. A. Thompson, Basin and Range rifting in northern Nevada: Clues from a mid-Miocene rift and its subsequent offsets, Geology, 6, 111-116, 1978

(Received April 19, 1979; accepted July 30, 1979.) 